\title{
Intubation Procedure
}

National Cancer Institute

\section{Source}

National Cancer Institute. Intubation Procedure. NCI Thesaurus. Code C37981.

The insertion of a cannula or tube into a hollow body organ. 